\title{
Peran Pendidikan Gizi dalam Meningkatkan Pengetahuan, Sikap dan Perilaku Gizi Seimbang pada Remaja di SMA YASMU Kecamatan Manyar Kabupaten Gresik
}

\author{
Dian Agnesia
}

\author{
STIKes Delima Persada Gresik, agnesia.d@gmail.com
}

\begin{abstract}
ABSTRAK
Obesitas merupakan suatu masalah yang cukup tinggi di masyarakat Indonesia, namun paling sering diabaikan. Obesitas menjadi masalah epidemic global yang harus segera ditangani dengan serius. Obesitas mengalami tren yang semakin meningkat hingga tahun 2018. Kegiatan pengabdian masyarakat ini bertujuan meningkatkan pengetahuan remaja terhadap makanan dan pentingnya menerapkan pola hidup yang sehat dan aktif dalam kehidupan sehari- hari. Pengetahuan akan mempengaruhi sikap dan perilaku seseorang dalam menerapkan gizi seimbang dalam kesehariannya. Perilaku gizi seimbang diharapkan dapat mengurangi masalah gizi di kalangan remaja dan hal ini akan terlihat dari pola makan remaja sehari- hari.

Pada kegiatan pengabdian masyarakat ini ditemukan partisipan dengan status gizi obes $(4 \%)$, overweight atau kelebihan berat badan $(21 \%)$ dan kurus (12\%). Pengetahuan partisipan mengalami peningkatan dengan kategori pengetahuan baik sebanyak $28 \%$ meningkat menjadi $38 \%$ setelah dilakukan Pendidikan Gizi. Sikap partisipan terkait dengan Pedoman Gizi Seimbang sebagian besar berada pada kategori kurang yaitu $(58 \%)$, sedangkan perilaku partisipan dalam menerapkan 4 pilar Gizi Seimbang masih kurang terutama terkait menjaga berat badan ideal $(58 \%)$ dan pola hidup aktif dan berolahraga (83\%).
\end{abstract}

Kata-kata Kunci: Obesitas, Pendidikan Gizi, Sikap, Perilaku, Pedoman Gizi Seimbang

\section{ABSTRACT}

Obesity is a problem that is quite high in Indonesian society, but is most often ignored. Obesity is a global epidemic problem that must be dealt with seriously. This incidence of obesity experiencing an increasing trend until 2018. This community service activity aims to increase adolescent knowledge of food and the importance of applying a healthy and active lifestyle in daily life. Knowledge will influence a person's attitude and behavior in applying balanced nutrition in their daily lives. Balanced nutrition behavior is expected to reduce nutritional problems among adolescents and this will be seen from the daily diet of teenagers. In this community service activity participants were found to be obese nutritional status (4\%), overweight or overweight (21\%) and thin (12\%). Participant's knowledge increased with the category of good knowledge by $28 \%$, increasing to $38 \%$ after Nutrition Education. The participant's attitude related to the Balanced Nutrition Guidelines was mostly in the less category (58\%), while the participant's behavior in applying the 4 pillars of Balanced Nutrition was still mainly related to maintaining an ideal body weight (58\%) and active and exercising lifestyle (83\%).

Keywords: Obesity, Nutrition Education, Attitude, Behavior, Balanced Nutrition Guidelines

\section{PENDAHULUAN}

Obesitas adalah sebuah kondisi dimana kelebihan lemak tubuh terakumulasi sedemikian rupa sehingga menimbulkan dampak kerugian bagi kesehatan. Kondisi ini dapat menurunkan harapan hidup dan meningkatkan masalah kesehatan. Hingga hari ini obesitas merupakan masalah kesehatan dunia yang dinyatakan oleh WHO sebagai sebuah epidemic global.

Hasil Riset Kesehatan Dasar Indonesia (Riskesdas) tahun 2018 menemukan bahwa proporsi berat badan lebih dan obes mengalami tren yang meningkat. Proporsi berat badan lebih dan obesitas pada dewasa sejak tahun 2007 hingga 2018 selalu mengalami 
peningkatan dari 8,6 menjadi 13,6 untuk berat badan berlebih, sedangkan proporsi obesitas dari 10,5 meningkat menjadi 21,8.

Masalah kelebihan berat badan dan obesitas ini masih tergolong tinggi terutama di beberapa kota besar di Indonesia. Data Riskesdas tahun 2013 menyebutkan bahwa Jakarta dan Jawa Timur adalah kota dengan prevalensi remaja dengan berat badan lebih dan obesitas diatas rata- rata nasional. Masalah ini tidak hanya terjadi pada anak saja, tetapi juga pada remaja. Proporsi berat badan lebih pada anak usia 5-12 tahun masih sangat tinggi $(18,8 \%)$, dengan proporsi anak obesitas sebesar $8,8 \%$. Sedangkan pada remaja usia 13- 15 tahun adalah sebesar $10,8 \%$, dengan status gizi berat badan lebih sebanyak $8,3 \%$ dan obesitas sebesar 2,5\%. Remaja dengan rentang usia 16- 18 tahun sebesar 7,3\%, dengan kategori obesitas $1,6 \%$, dan sisanya $5,7 \%$ masuk dalam kategori berat badan lebih.

Di masyarakat Indonesia saat ini kondisi obesitas merupakan salah satu masalah yang cukup tinggi namun paling sering diabaikan, hal ini mengakibatkan obesitas menjadi kejadian epidemic global. Penyebab utama masalah obesitas berasal dari pola makan. Data Global School Health Survey (2015) menyebutkan pola makan remaja yang sering melewatkan sarapan $(65,2 \%)$, kurang mengkonsumsi serat dari sayur dan buah $(93,6 \%)$, sering mengkonsumsi makanan berpenyedap yang tinggi natrium $(75,7 \%)$ serta kurangnya aktivitas fisik (42,5\%) adalah penyebab tingginya jumlah obesitas saat ini.

Tujuan dari kegiatan pengabdian masyarakat ini adalah meningkatkan pengetahuan remaja terhadap makanan dan pentingnya menerapkan pola hidup yang sehat dan aktif dalam kehidupan sehari- hari. Penambahan pengetahuan ini diharapkan dapat merubah sikap dan perilaku remaja dalam hal pola makan serta dapat menularkan perilaku sehatnya kepada keluarga dan masyarakat di sekitarnya. Upaya yang dilakukan yaitu melalui screening status gizi, pemberian pendidikan mengenai gizi seimbang, serta demonstrasi aktivitas fisik bagi remaja.

\section{METODE PENGABDIAN MASYARAKAT}

\subsection{Rancangan Kegiatan}

Pengabdian masyarakat ini dikembangkan dengan pendekatan ilmiah. Rangkaian pendekatan ilmiah tersebut meliputi identifikasi permasalahan, menentukan tujuan, manfaat kegiatan, merancang prosedur pengabdian masyarakat, melakukan analisis terhadap data dan informasi, serta menjelaskan data dan menarik kesimpulan (lihat Gambar 1). 


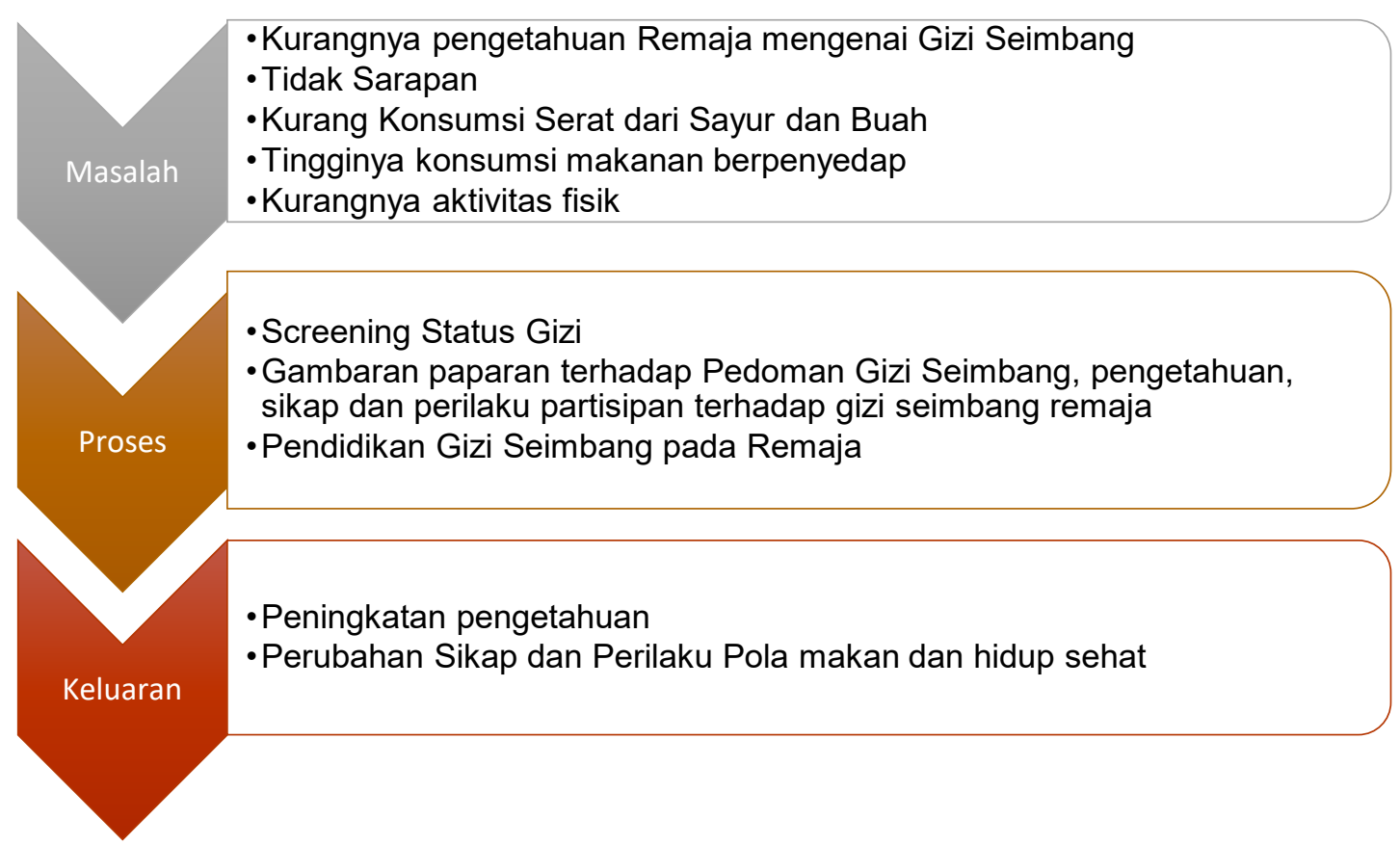

Gambar 1. Rancangan Kegiatan Pengabdian Masyaraka

\subsection{Lokasi dan Partisipan}

Lokasi kegiatan adalah di SMA Yasmu Gresik. Dipilinnya SMA ini, karena lokasi sekolah yang berada di wilayah perkotaan, salah satu sekolah menengah atas yang memiliki karakteristik siswa yang berasal dari latar belakang sosial ekonomi yang beragam. Partisipan kegiatan adalah siswa- siswi kelas X dan XI dengan rentang usia 15- 18 tahun.

\subsection{Bahan dan Alat}

Data primer didapatkan dari pengukuran langsung, kuesioner dan wawancara kepada partisipan. Kuesioner yang digunakan meliputi, karakteristik, pengetahuan tentang gizi seimbang pada remaja, sikap dan perilaku terhadap makanan, serta pengukuran antropometri terhadap partisipan.

\subsection{Metode Pelaksanaan Kegiatan}

Adapun langkah- langkah yang digunakan dalam penyelesaian persoalan masyarakat tersebut, yaitu:

\section{a. Screening Status Gizi}

Screening status gizi dilakukan melalui pengukuran antropometri kepada partisipan yang terlibat dalam kegiatan ini. Tujuan tahapan ini adalah untuk mengetahui gambaran status gizi partisipan saat ini. Rincian kegiatan yang dilakukan adalah meliputi: 
1) Pengumpulan data partisipan meliputi nama, tanggal lahir, jenis kelamin, dan usia.

2) Pengukuran Tinggi Badan

3) Pengukuran Berat Badan

4) Analisa Indeks Massa Tubuh (IMT). Analisa ini dilakukan untuk menentukan status gizi partisipan

\section{b. Gambaran}

Paparan terhadap Pedoman Gizi Seimbang (PGS), pengambilan keputusan terkait makanan serta sikap dan perilaku partisipan terhadap pola makan yang baik.

Langkah ini dilakukan untuk memberikan gambaran secara garis besar terkait keterpaparan partisipan terhadap PGS, bagaimana partisipan mengambil keputusan terkait makanan, pengetahuan dasar tentang gizi serta sikap dan perilaku partisipan terhadap pola makan yang baik. Hal ini dilakukan sebagai indikator ada atau tidaknya perubahan setelah diberikan edukasi gizi. Gambaran tersebut didapatkan dengan memberikan kuesioner berisi pertanyaan kepada partisipan.

\section{c. Pemberian Pendidikan Gizi}

Pendidikan gizi adalah serangkaian kegiatan terstruktur yang dilakukan dengan tujuan meningkatkan pengetahuan partisipan. Materi pendidikan gizi yang diberikan meliputi,

1) Pengertian remaja,

2) Kebutuhan gizi remaja,

3) Keseimbangan gizi

4) Masalah gizi pada remaja

5) Pola hidup sehat pada remaja

\section{d. Pengolahan dan Analisis Data}

Pengolahan data dengan menggunakan tabulasi data diolah dengan menggunakan program excel. Pengabdian masyarakat dilakukan dengan menggunakan metode survei dimana sampel diambil berdasarkan pertimbangan keterwakilan ciri- ciri fenomena populasi. Dalam analisis data pengabdian lapangan akan di dukung oleh data kuantitatif dan kualitatif, untuk mengontrol informasi yang bersifat kualitatif diperlukan informasi data kuantitatif sedangkan untuk memperjelas data kuantitatif diperlukan data kualitatif.

\section{HASIL DAN PEMBAHASAN}

Kegiatan pengabdian masyarakat kepada siswa SMA Yasmu telah dilaksanakan dengan melibatkan pihak sekolah dan Dinas terkait. Hasil kegiatan pengabdian masyarakat adalah sebagai berikut: 


\section{1. Screening Status Gizi}

Status gizi adalah keadaan tubuh sebagai akibat dari konsumsi makanan dan penggunaan zat- zat gizi di dalam tubuh (Almatsier, 2003). Penilaian status gizi dapat dilakukan secara langsung maupun tidak langsung. Salah satu pengukuran status gizi secara langsung adalah menggunakan pengukuran Indeks Massa Tubuh (IMT). IMT merupakan hasil pembagian berat badan dalam kilogram dengan tinggi badan kuadrat dalam meter $\left(\mathrm{BB}(\mathrm{kg}) / \mathrm{TB}^{2}(\mathrm{~m})\right)$. Kegiatan pengukuran tinggi badan dan berat badan dapat dilihat pada Gambar 2.

Gambar 3 menunjukkan distribusi status gizi partisipan berdasarkan IMT, sebagian besar partisipan memiliki status gizi normal (63\%), namun masih ditemukan partisipan dengan status gizi obes (4\%), overweight atau kelebihan berat badan (21\%) dan kurus (12\%). Hal ini menandakan beberapa partisipan masih memiliki pola konsumsi makan yang kurang baik.
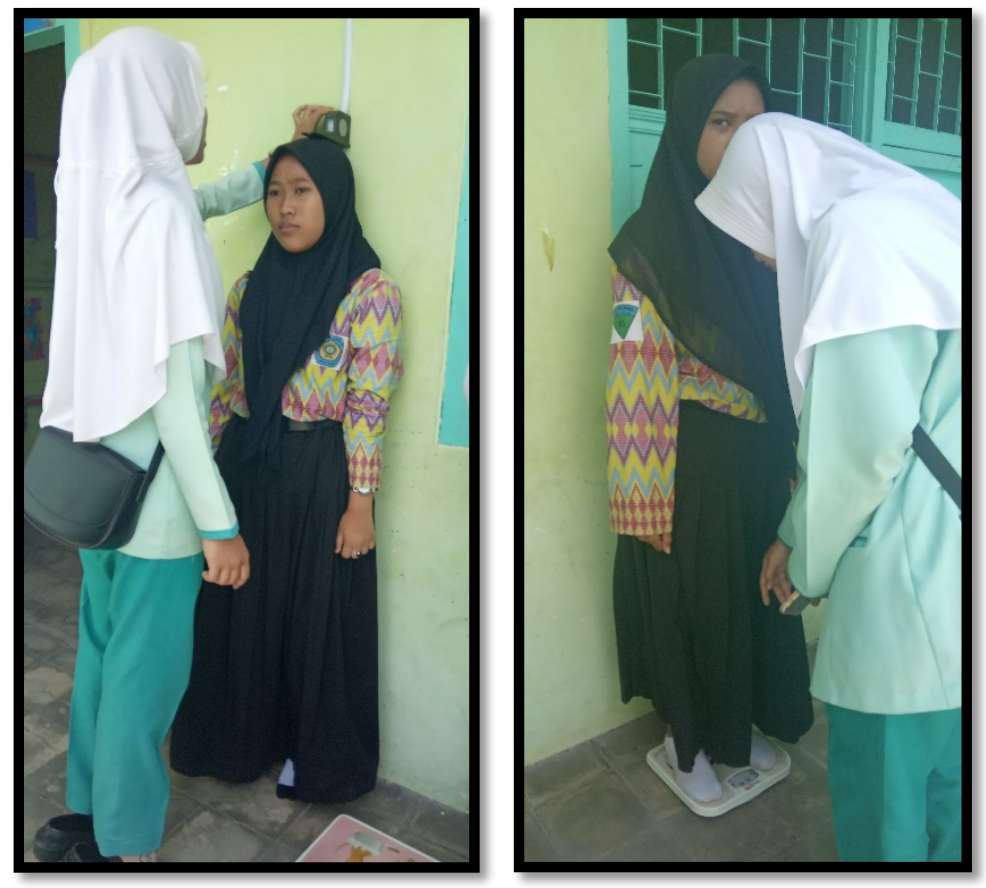

Gambar 2. Pengukuran Tinggi Badan dan Berat Badan Partisipan 


\section{Status Gizi (IMT)}

\section{$1 ; 4 \% \quad 3 ; 12 \%$}

\section{$5 ; 21 \%$}

\section{Gambar 3. Distribusi Status Gizi Partisipan berdasarkan IMT}

\section{2. Pendidikan Gizi}

Pendidikan gizi adalah salah satu unsur yang dapat meningkatkan status gizi masyarakat dalam jangka panjang. Sosialisasi maupun penyampaian pesan- pesan gizi yang aplikatif akan mampu membentuk gaya hidup dengan pola makan masyarakat yang seimbang. Pendidikan gizi diharapkan mampu meningkatkan pengetahuan remaja sehingga mampu merubah kebiasaan makan menjadi pola makan yang seimbang.

Tujuan pendidikan gizi dibagi menjadi jangka panjang dan jangka pendek. Tujuan jangka pendek pendidikan gizi yaitu mendapatkan pengetahuan, mampu membangun kerangka konsep prinsip- prinsip gizi, membangun sikap positif terhadap kebiasaan gizi yang baik hingga mampu menggunakan pengetahuan gizi tersebut dalam pemilihan makanan. Sedangkan tujuan jangka panjangnya adalah untuk mengatur, mencari dan mau menerima pengetahuan tentang gizi serta pada akhirnya mampu menseleksi makanan yang bergizi dari hari ke hari sepanjang hidup untuk memelihara kesehatan, kesejahteraan dan produktivitas (Emilia, 2009).

Pendidikan gizi pada kegiatan pengabdian masyarakat ini dilakukan dalam bentuk ceramah, tanya jawab dan demonstrasi (lihat Gambar 4). Materi pendidikan yang diberikan diantaranya adalah pengertian masa remaja, kebutuhan gizi pada remaja, keseimbangan gizi, masalah gizi dan pola hidup sehat pada remaja. 

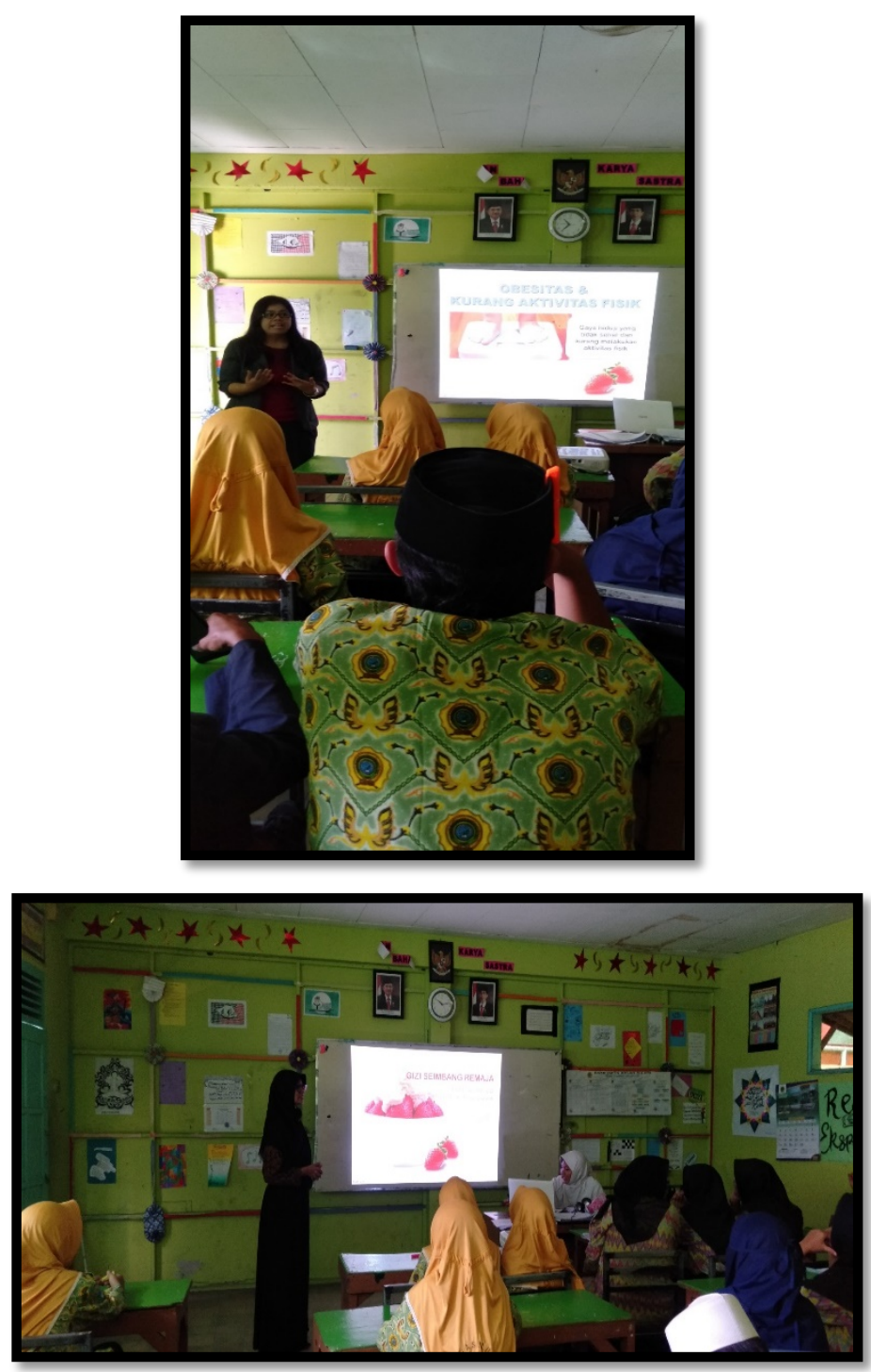

Gambar 4. Pemberian Pendidikan Gizi

\section{3. Pengetahuan}

Pengetahuan akan mempengaruhi sikap dan perilaku seseorang dalam menerapkan gizi seimbang dalam kesehariannya. Perilaku gizi seimbang diharapkan dapat mengurangi masalah gizi di kalangan remaja dan hal ini akan terlihat dari pola makan remaja seharihari.

PGS adalah penyempurnaan Pedoman Umum Gizi Seimbang pada tahun 2003. Pedoman ini telah dikenalkan dan disosialisasikan kepada masyarakat oleh petugas kesehatan dari berbagai institusi baik pemerintah maupun non pemerintah dalam rangka melaksanakan pendidikan gizi seimbang kepada masyarakat.

Gambar 5 menunjukkan distribusi keterpaparan partisipan terhadap PGS. Sebagian besar partisipan (65\%) sudah mengenal PGS dan media sebagai sumber pengenalan PGS oleh partisipan, paling banyak berasal dari media buku, televisi dan internet (Gambar 6). 


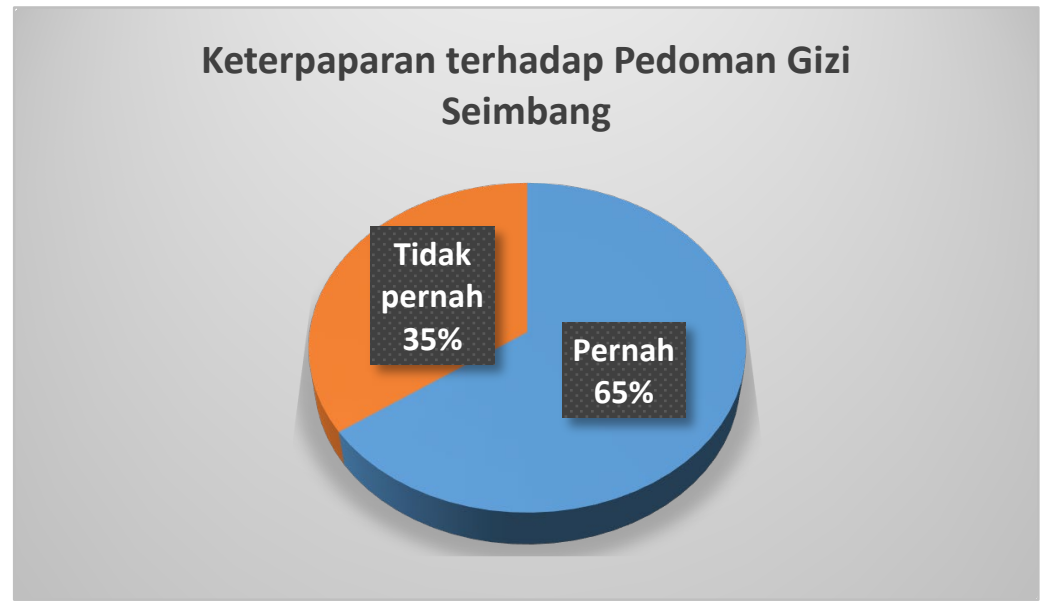

Gambar 5. Distribusi Keterpaparan terhadap PGS

\section{Sumber Media}

Siswa mengetahui PUGS melalui media lainnya. Siswa mengetahui PUGS melalui media petugas. Siswa mengetahui PUGS melalui media orang tua Siswa mengetahui PUGS melalui media teman Siswa mengetahui PUGS melalui media guru Siswa mengetahui PUGS melalui media internet Siswa mengetahui PUGS melalui media radio Siswa mengetahui PUGS melalui media televisi Siswa mengetahui PUGS melalui media poster Siswa mengetahui PUGS melalui media brosur Siswa mengetahui PUGS melalui media leaflet Siswa mengetahui PUGS melalui media buku Siswa mengetahui PUGS melalui media majalah Siswa mengetahui PUGS melalui media koran

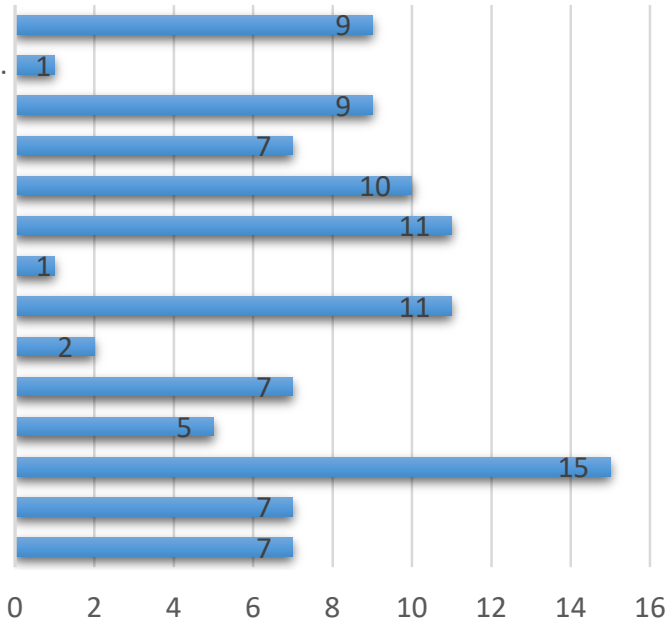

Gambar 6. Distribusi Sumber Media Paparan Partisipan terhadap PGS

Masa remaja adalah masa dimana teman dan lingkungan memiliki pengaruh yang sangat besar dalam pengambilan keputusan. Termasuk dalam pola makan. Kebiasaan remaja suka bergaul, berkumpul dan bersama pada waktu makan sehingga terkadang pengambilan keputusan makan pada remaja dipengaruhi oleh lingkungan dan teman sebayanya. Gambar 7 menunjukkan pengambilan keputusan terkait makanan pada partisipan sebagian besar partisipan menentukan makanannya sendiri walaupun saat membeli makanan bersama dengan orang tua/ saudara/ kakak/ adik. Dan hampir sebagian besar partisipan sering membeli makanan dengan teman sebayanya. 


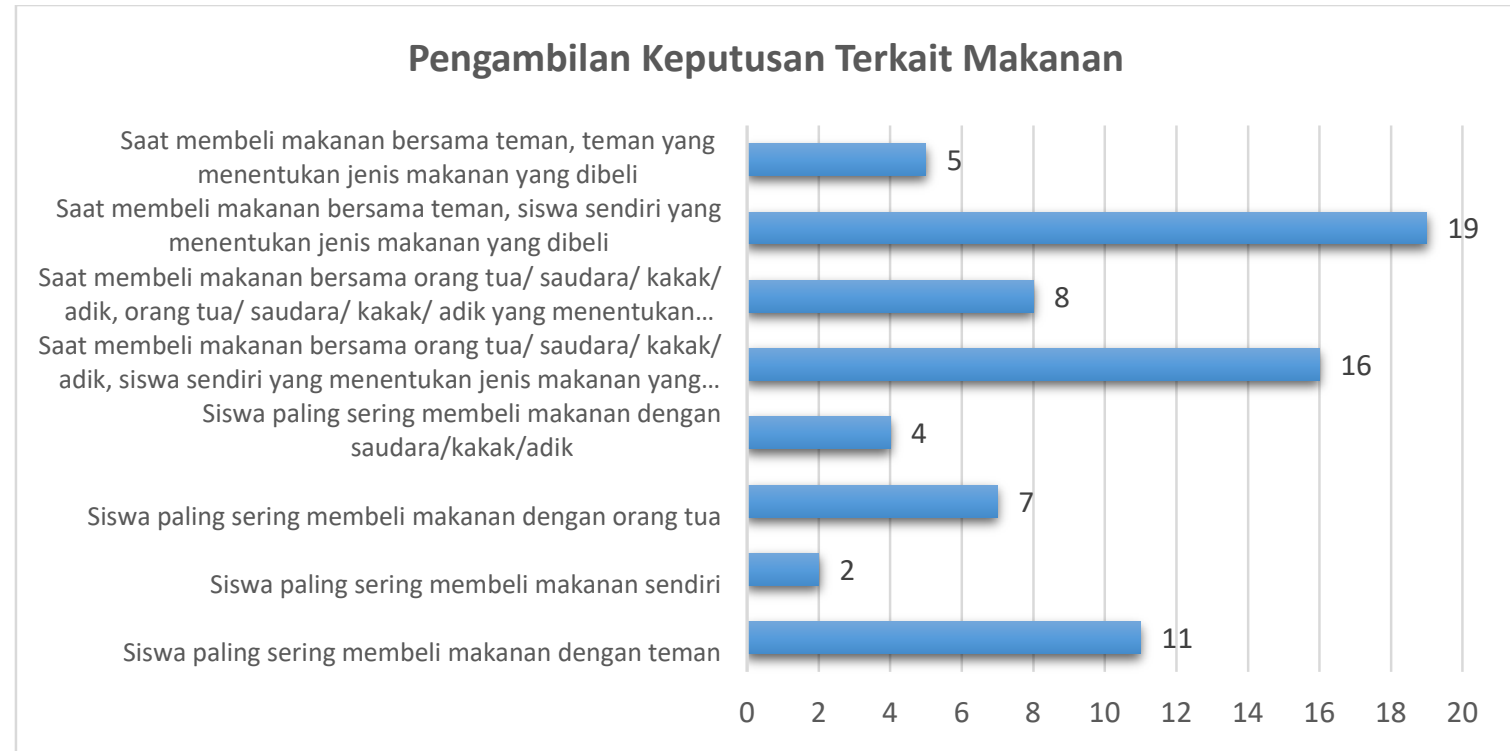

Gambar 7. Distribusi Pengambilan Keputusan Terkait Makanan Partisipan

Pengambilan keputusan seseorang dalam menentukan suatu tindakan (perilaku) sangat ditentukan oleh pengetahuan yang dimiliki. Sebelum diberikan pendidikan gizi, partisipan diberikan kuesioner dengan beberapa pertanyaan mendasar terkait gizi seimbang pada remaja, dan Gambar 8 menunjukkan hasil bahwa sebagian besar partisipan $(72 \%)$ memiliki pengetahuan gizi yang kurang. Pengetahuan didasari oleh beberapa faktor antara lain sosial, ekonomi, budaya, kondisi kesehatan dan lain sebagainya. Setelah dilakukan pendidikan gizi, Gambar 9 menunjukkan jumlah partisipan yang memiliki pengetahuan mengenai gizi seimbang meningkat menjadi $38 \%$.

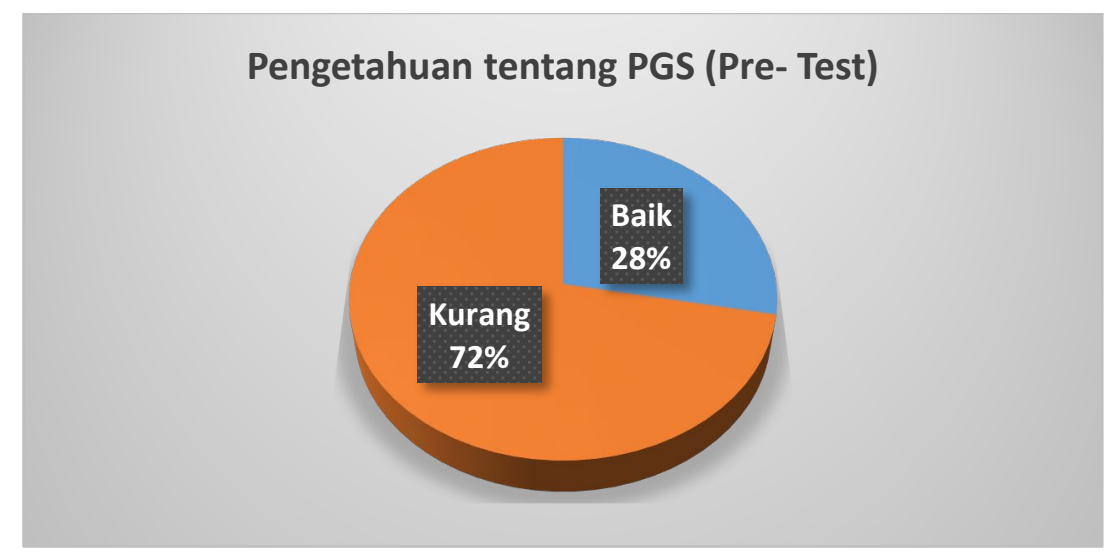

Gambar 8. Distribusi Pengetahuan Partisipan terhadap PGS (Pre- Test) 


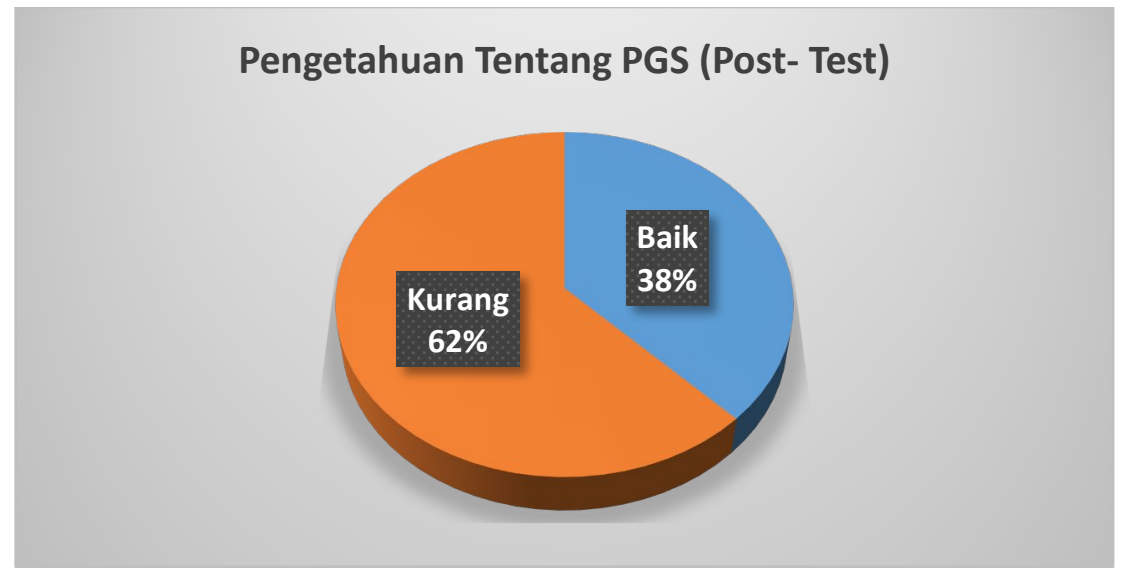

Gambar 9. Distribusi Pengetahuan Partisipan terhadap PGS (Post- Test)

\section{4. Sikap dan Perilaku Makan}

PGS telah diimplementasikan di Indonesia sejak tahun 1955 dan merupakan realisasi dari rekomendasi Konferensi Pangan Sedunia di Roma tahun 1992. PGS menggantikan slogan "4 sehat 5 sempurna" yang telah diperkenalkan sejak tahun 1952 dan sudah tidak sesuai lagi dengan perkembangan ilmu pengetahuan dan teknologi (IPTEK) di bidang gizi. Dengan mengimplementasikan PGS diyakini bahwa masalah gizi dapat diatasi.

Gambar 10 menunjukkan distribusi sikap partisipan terhadap PGS masih kurang (53\%). Hal ini menunjukkan PGS masih belum banyak dipahami oleh masyarakat, terutama remaja. PGS memuat zat gizi dalam jenis dan jumlah (porsi) yang sesuai dengan kebutuhan setiap orang atau kelompok umur. Konsumsi makanan harus pula memperhatikan prinsip 4 pilar gizi seimbang, yaitu anekaragam pangan, perilaku hidup bersih, aktivitas fisik dan mempertahankan berat badan normal. Pada kegiatan pengabdian masyarakat ini hampir sebagian besar partisipan masih memiliki perilaku makan yang kurang sesuai dengan PGS (Gambar 11), terutama dalam hal menjaga berat badan ideal (58\%) dan pola hidup aktif dan berolahraga (83\%).

Pola makan merupakan perilaku paling penting yang dapat mempengaruhi keadaan gizi seseorang. Mencegah terjadinya penyakit kronis atau penyakit tidak menular (PTM) terkait gizi, maka pola makan masyarakat harus ditingkatkan kearah konsumsi gizi seimbang. Gizi yang optimal akan meningkatkan pertumbuhan dan perkembangan fisik dan kecerdasan pada kelompok umur remaja. Gizi yang baik akan menjaga berat badan ideal, tubuh tidak mudah terkena penyakit infeksi, produktivitas meningkat serta terlindung dari penyakit kronis dan kematian dini.

Keberhasilan penyampaian pesan gizi seimbang kepada masyarakat sangat dipengaruhi oleh komunikasi, informasi dan edukasi yang diterapkan. Agar pesan ini dapat sampai kepada masyarakat yang berdampak pada perubahan perilaku, maka diperlukan strategi dan implementasi KIE yang tepat dan berbasis masyarakat. 


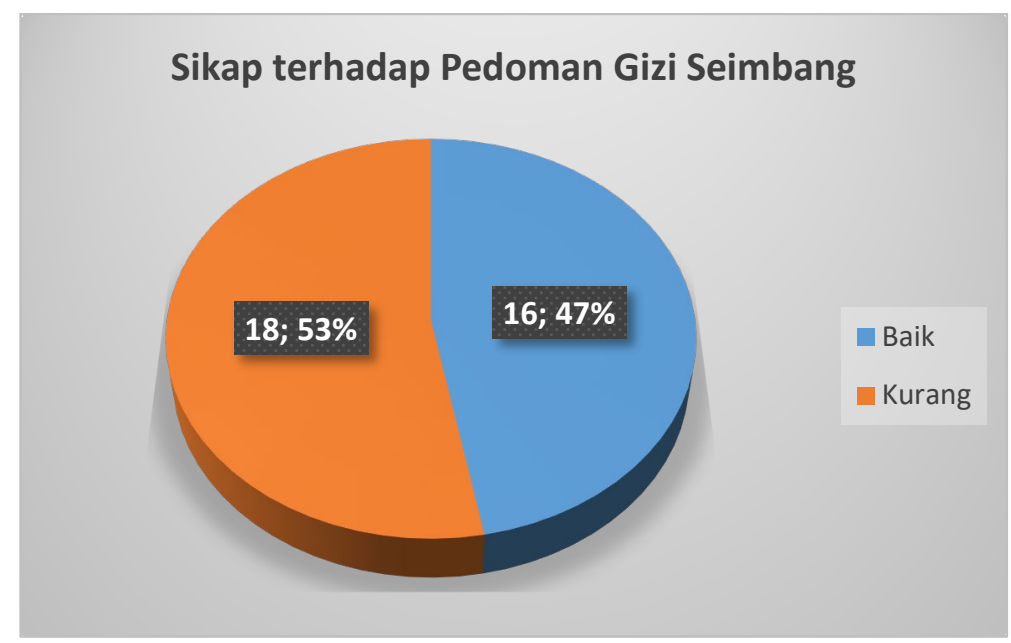

Gambar 10. Distribusi Sikap terhadap PGS

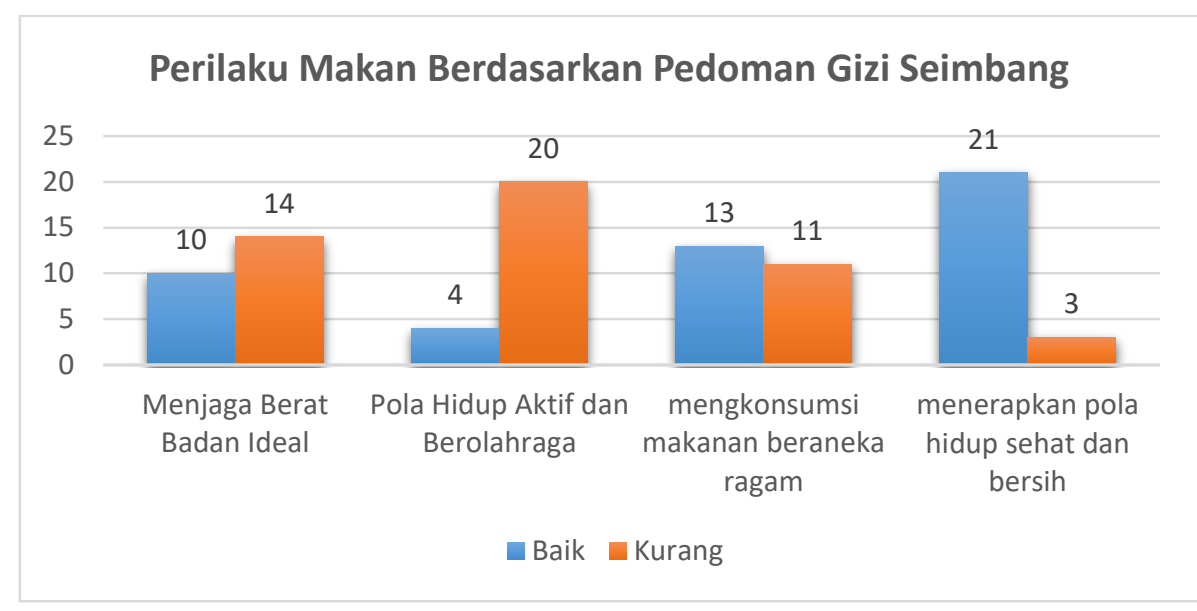

Gambar 11. Perilaku Makan Berdasarkan PGS

Akhirnya kegiatan pengabdian kepada masyarakat ini ditutup dengan foto bersama anatar pelaksana dengan pihak sekolah (Gambar 12). 


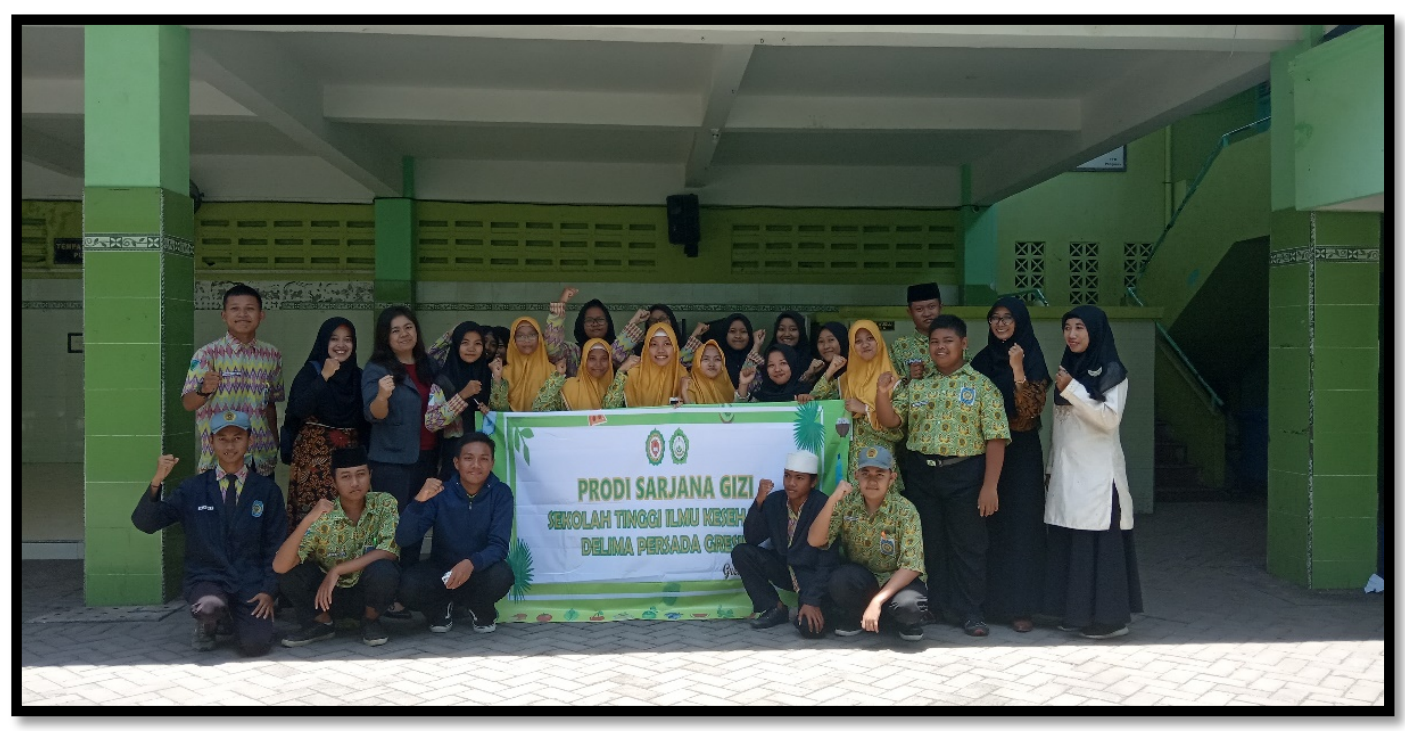

Gambar 3.4.3. Sesi Foto beberapa Partisipan, Pelaksana dan Guru SMA Yasmu Gresik

\section{KESIMPULAN}

a. Status gizi partisipan sebagian besar normal (63\%), namun masih ditemukan partisipan dengan status gizi obes (4\%), overweight atau kelebihan berat badan $(21 \%)$ dan kurus $(12 \%)$.

b. Pengetahuan partisipan mengalami peningkatan setelah dilakukan Pendidikan Gizi. Pada saat dilakukan pre- test jumlah partisipan yang tergolong kategori baik sebanyak 28\% dan meningkat menjadi 38\% setelah dilakukan Pendidikan Gizi.

c. Sikap partisipan terkait dengan PGS sebagian besar berada pada kategori kurang (58\%). Demikian pula dengan perilaku partisipan tentang PGS juga masih masuk dalam kategori kurang, terutama dalam hal menjaga berat badan ideal (58\%) dan pola hidup aktif dan berolahraga (83\%).

d. Pola makan merupakan perilaku paling penting yang akan mempengaruhi status gizi remaja. Gizi yang optimal akan meningkatkan pertumbuhan, perkembangan fisik, kecerdasan serta mencegah terjadinya penyakit kronis, penyakit tidak menular terkait gizi, dan kematian dini.

\section{UCAPAN TERIMA KASIH}

a. Kepala Sekolah SMA Yasmu Manyar

b. Guru dan staf SMA Yasmu Manjar

c. Ketua, Kepala P3M STIKes Delima Persada Gresik dan Dosen-Dosen Tim Pengabdian Masyarakat Prodi Sarjana Gizi STIKes Delima Persada Gresik 


\section{DAFTAR PUSTAKA}

Almatsier, S. (2003). Prinsip Dasar IImu Gizi. Jakarta: Gramedia Pustaka Utama.

Emilia. (2009). Pengetahuan, Sikap dan Praktek Gizi pada Remaja dan Implikasinya pada Sosialisasi Perilaku Hidup Sehat. Jurnal Media Pendidikan Gizi dan Kuliner, 1(1).

Ermona \& Wirjatmadi. (2018). Hubungan Aktivitas Fisik dan Asupan Gizi dengan Status Gizi Lebih Pada Anak Usia Sekolah Dasar di SDN Ketabang 1 Kota Surabaya Tahun 2017. Amerta Nutrition, 2(1).

Haslam D.W., James W.P. (2005). Obesity. The Lancet, 366(9492).

Kementerian Kesehatan Republik Indonesia. (2012). Pedoman Pencegahan dan Penanggulangan Kegemukan dan Obesitas pada Anak Sekolah. Jakarta: Kementerian Kesehatan RI.

Kementerian Kesehatan RI. (2014). Pedoman Gizi Seimbang. Jakarta: Direktorat Bina Gizi dan KIA.

Kementerian Kesehatan RI Badan Penelitian dan Pengembangan Kesehatan. (2013). Pokok- Pokok Hasil Riskesdas Indonesia 2013. Jakarta: Balitbang Kemenkes.

Kementerian Kesehatan RI Badan Penelitian dan Pengembangan Kesehatan. (2018). Laporan Nasional Riskesdas 2018. Jakarta: Balitbang Kemenkes.

Kussoy, K., Fatimawali, Kepel, B. (2013). Prevalensi Obesitas pada Remaja di Kabupaten Minahasa. Jurnal e-biomedik (eBM), 1(2).

Permatasari, I.R.I., Mayulu, N., Hamel, R. (2013). Analisa Riwayat Orang Tua sebagai Faktor Resiko Obesitas pada Anak SD di Kota Manado. Ejournal Keperawatan (e-Kp), 1(1). 